\title{
Effectiveness Correlates of School Leadership Styles and Teachers' Job Satisfaction: A Meta-Analytic Review
}

\section{Research Article}

\section{Erkan GOKTAS ${ }^{1}$}

${ }^{1}$ Selçuk University, Faculty of Education, Department of Educational Management, Konya, Turkey, ORCID: 0000- 0002-3150-0142

To cite this article: Goktas, E. (2021). Effectiveness correlates of school leadership styles and teachers' job satisfaction: A meta-analytic review, International Online Journal of Educational Sciences, 13(4), 1023-1044.

\author{
ARTICLE INFO \\ Article History: \\ Received: 23.10 .2020 \\ Available online: \\ 08.09.2021
}

\begin{abstract}
The main purpose of this study is to determine the correlational effect of school leadership styles on teachers' job satisfaction in the context of Turkey. Following a meta-analysis model, this study conducts a quantitative systematic review combining similar statistical data to obtain an aggregate score. Eligible correlational studies conducted in Turkey were included in the meta-analysis. The fullrange leadership model is available to measure its effects by Multifactor Leadership Questionnaire (MLQ). It was the basic scale of the studies included. The main scale for job satisfaction in the studies is Minnesota Satisfaction Questionnaire (MSQ). The studies selected for meta-analysis employed the MLQ and/or MSQ. The findings reached revealed there to be a strong correlation between transformational leadership and teacher's job satisfaction, which had a large, positive effect. There is a positive correlation between transactional leadership and teachers' job satisfaction, which had a moderate positive effect. Lastly, there is a negative correlation between laissez-faire leadership and teachers' job satisfaction, which had a small, negative effect. The moderator variables (i.e., publication type, school level, and region) were significant for the transformational leadership style. The moderator variables that were statistically significant for transactional leadership were school level and the region where the study was conducted. The only significant moderator for laissez-faire leadership was the region. The study concluded that transformational and transactional school leadership styles had the greatest effect on teachers' job satisfaction. School leaders should avoid laissez-faire leadership behaviors.
\end{abstract}

(C) 2021 IOJES. All rights reserved

\author{
Keywords: \\ Leadership, Job satisfaction, Meta-analysis
}




\section{Introduction}

A considerable number of studies on leadership have been conducted throughout the world. Leadership styles are heavily researched by scholars, who then make practical recommendations based on the results. Educational institutions benefit from these recommendations by adjusting their leadership and management styles. Educational institutions and their administration must become accustomed to renewing itself. It is impossible for organizations to survive in today's competitive world unless they come up with new ideas and create change. Leading, world-renowned educational institutions are those that have adopted effective leadership strategies capable of meeting the ever-changing requirements of the times. Given that educational institutions are different from other types of organizations, having dynamic leadership is a must so that schools may stay abreast with prevailing leadership qualifications. Having human beings as their capital, it is imperative that educational institutions espouse the most effective leadership style so as to nurture the desired human qualifications through education.

Burns (1978) introduced both transformational and transactional leadership, after which several scholars (Bass, 1985; Bass, 1998; Avolio \& Bass, 1995; Judge \& Piccolo, 2004; Avolio \& Bass, 2002) made important contributions to the literature on leadership, bringing leadership theory to its current form. Bass and Avolio (1997) developed a comprehensive model, which they dubbed the full-range leadership model, and the Multifactor Leadership Questionnaire (MLQ), able to measure the full range of leadership qualifications (Avolio \& Bass, 1995). This model of leadership divides leadership into three main styles, namely, transformational, transactional, and laissez-faire. The current study, however, focuses on the correlational effects of the full-range leadership model on teachers' job satisfaction levels in Turkey vis-à-vis transformational, transactional, and laissez-faire school leadership styles. As the main scale to measure job satisfaction, the Minnesota Satisfaction Questionnaire (MSQ) developed by Weiss, Dawis, England, and Lofquist (1967) was taken into consideration. These two scales are the main instruments employed to measure leadership styles' correlational effect on job satisfaction in the studies subject to meta-analysis in the current study.

\section{Transformational Leadership}

Transformational leaders help people distinguish between leadership styles. First, transformational leaders help their followers grow and themselves become leaders by responding to individual followers' needs, empowering them, and harmonizing the objectives and goals of each follower, the leader, the group, and the larger organization. Evidence has accumulated demonstrating that transformational leadership can propel followers to exceed performance expectation and to attain high levels of follower satisfaction and commitment toward the group and organization (Bass, 1985, 1998).

Transformational leaders undertake several roles to achieve their goals. They have a sophisticated, yet succinct way of behaving. Moreover, although followers may sometimes misunderstand them, their comprehensive leadership style is able to reconcile problems. Concerning performance, transformational leaders sometimes give directions but are also active participants in the process. Followers see them as democratic, authoritarian, elitist, or equalizing. The dynamic nature of their characteristics may cause followers to mistake them for being elitist and antidemocratic (Avolio \& Bass, 2002).

Distinguishing themselves from other types of leaders, transformational leaders have more interactions with their colleagues and followers. Through simple exchanges and agreements, they transform followers' behaviors into premeditated, goal-oriented activities. The core components of transformational leadership were determined by Avolio, Bass, and Jung (1999) and can be measured by MLQ. These components are idealized influence, inspirational motivation, intellectual stimulation, and individualized consideration (Bass \& Riggio 2006). 
Idealized influence: Transformational leaders act as role models to their followers, whose actions and appearance are respected and admired. They influence followers in such a way that tend to be imitated. Furthermore, their followers perceive them as having extraordinary capabilities, high levels of persistence, and deep determination. The two aspects of idealized influence are the leader's behaviors and elements that are allotted to the leader by followers and other associates.

Inspirational motivation: Transformational leaders motivate their followers by providing meaning and created challenges for them to complete. Followers know what their job requires of them and are motivated to overcome difficulties. This motivation creates a team atmosphere that inspires hope and excitement in team members, makes them stakeholders in the organization's future, and, by creating a shared vision and boosting commitment, bolsters effective communication. Inspirational motivation leads the followers act as a team not as an individual.

Intellectual stimulation: Transformational leaders nurture their followers' desire to be creative and innovative by including them in the decision-making process of the organization. Followers can suggest new ideas and are not prevented from vocalizing their opinions. These opportunities are a result of leaders' effective transformational style. Through intellectual stimulation the followers search for new ideas and opinions that help participating organizational processes.

Individualized consideration: Transformational leaders consider each person as an important element of the organization. They pay careful attention to the needs of every individual and offering their followers guidance so that they may be successful is a priority for them. By considering individuals' personal needs and learning styles, they create a supportive organizational climate in which followers are able to achieve their goals. Well guided individuals as an important component of the organization can make contributions to achieve organizational goals because of being considered separately.

\section{Transactional Leadership}

Transactional leaders compel their followers to perform their best and to achieve their objective through either reward or punish. Contingent rewards form the basis for effective transactional leadership. Furthermore, if transactional leaders improve their leadership skills, they will be more effective, innovative, risk-taking, and satisfied (Avolio \& Bass, 2002).

Transactional leadership is based on discipline where leaders manage the organization through rewards and penalties to followers' performance. Transactional leaders control the processes through either positive contingent rewards or management-by-exception (Bass \& Riggio, 2006).

Contingent reward: This is a tool used to motivate followers. Transactional leaders make it clear when one becomes eligible for a reward. This clear understanding makes followers work in such a way that would cause them to deserve reward.

Management-by-exception: This is a corrective tool employed to manage followers. In the event of failure, the leader intervenes to make followers take certain actions to meet performance standards. In this type of management, the leader may not take action unless complaints are received.

\section{Laissez-faire Leadership}

Laissez-faire leaders allow their followers to do what they want, as this style eschews autocratic leadership. In fact, it may be described as the absence of leadership. Even in case of serious problems, this type of leader avoids involving him/herself in them (Bass \& Riggio, 2006). Consequently, laissez-faire leadership is not expected to have a positive effect on job satisfaction. Although teachers require external motivation to work effectively, laissez-faire leadership does not provide this motivational support. Therefore, motivational problems are inevitable and a detrimental effect on satisfaction. 


\section{Job Satisfaction}

There is no single definition of job satisfaction. One of the most cited definitions was made by Locke (1976), who considers job satisfaction to refer to how happy and content a person is about his/her work or simply whether the individual likes the job or not. Others, however, draw attention to a person's psychological responses to the job (Hulin \& Judge, 2003). The Routledge Dictionary of Business defines job satisfaction as the extent to which a worker feels contented with his or her job, especially in terms of intrinsic motivation (Statt, 2004). Newstrom (2007) suggests that job satisfaction is a set of favorable or unfavorable feelings and emotions through which employees perceive their work. Therefore, job satisfaction is an attitude related to feelings, thoughts, and intentions. A worker satisfied with his/her job expresses his/her feelings accordingly, shares his/her thoughts about his/her job, and can talk about future intentions regarding either continuing or leaving the job.

Teachers are among the frailest workers and frequently need to be motivated and feel a sense of security, energy, and enthusiasm to do their job effectively. Keeping them in a good mood requires efficient leadership, as influential leadership can increase teachers' motivation, in turn, leading to greater job satisfaction. As an organization, effective leadership and job satisfaction are absolutely necessary if educational institutions are to survive in this competitive age. According to Northouse (2010), teachers satisfied with their job have higher levels of morale, inspiration, and enthusiasm. These qualities help teachers enhance their potentials.

In educational literature, teachers' job satisfaction levels have an affective relation with their roles as teachers. It also describes the perception of the desired and offered forms of teaching in the real world (Papanastasiou \& Zembylas, 2005). There are two main components of teacher job satisfaction: job comfort and job fulfillment. Job comfort is the satisfaction level related to job conditions and circumstances. Job fulfillment is the extent to which an individual's personal accomplishments pertaining to meaningful aspects of his/her job come true (Evans, 1997). On the other hand, teachers' job satisfaction factors can be categorized as either intrinsic or extrinsic. Intrinsic factors of teachers are related to classroom activities with students (Papanastasiou \& Papanastasiou, 1998). Extrinsic factors, however, are associated with teachers' salaries, school principals' support, teaching resources, work load, and extra-curricular assignment expectations (Thompson, McNamara, \& Hoyle, 1997).

Studies exploring job satisfaction generally investigate business organizations. The findings confirm that leadership behaviors (such as initiating structure and consideration, creating positive atmosphere at work, providing stability in work, good relations with the followers, efficient management) have a profound and consistent influence on employees' job satisfaction levels (Palupi, Cahjono, \& Satyawati, 2017; Sypniewska, 2013; Qasim, Cheema, \& Syed, 2012; Hayta, 2007; Griffin \& Bateman, 1986; Steers \& Rhodes, 1978). In the same manner, results of the studies conducted in school settings have also shown that leaders' behaviors and school working conditions influence teachers' job satisfaction (Toropova, Myrberg, \& Johansson, 2020; Lytle, 2013; Bursalığlu, 2010; Bolin, 2007; Bogler, 2001; Dinham \& Scott, 2000; Ostroff, 1992; Morris \& Sherman, 1981).

\section{Relevant Studies}

Studies exploring leadership conducted in Turkey are generally focused on the relation between a leadership style and qualification, such as commitment, cynicism, and gender. Some studies review leadership styles and job satisfaction as a subcategory of the research problems. A limited number of meta-analyses conducted on leadership and school outputs review the leadership style and job satisfaction as a sub-problem. This study investigates school leadership styles' effect on teachers' job satisfaction in terms of the full-range leadership model developed by Bass and Avolio (1997). The effect of school principals' transformational, transactional, and laissez-faire leadership styles on teachers' job satisfaction were subject to a meta-analysis. 
The correlational studies included in this meta-analysis investigated the relation between school leadership styles and teachers' job satisfaction in different school levels. Eleven studies were theses (Tura, 2012; Canpolat Kirpik, 2019; Genç Yücel, 2019; Yılmaz, 2014; Akyol Kılıç, 2014; Aslan, 2013; Kete, 2015; Benibol, 2015; Çulha, 2017; Çelebi, 2012; Kul, 2010) whereas the other five were in article format (Eğriboyun, 2015; Tok \& Bacak, 2015; Tanrıverdi \& Paşaoğlu, 2014; Taş, 2017; Başaran \& Güçlü, 2018). Although they review certain additional qualifications (e.g., commitment and burnout), all of the studies examine leadership styles and job satisfaction. Starting from this point, the findings of all studies pertaining to correlation coefficients are combined to obtain a common correlation through the meta-analytical process.

The number of meta-analyses conducted on the same topic in Turkey is limited. No meta-analysis resembling the current study, which is strictly a review of the full range of school leaders' leadership styles and teachers' job satisfaction, has been conducted in Turkey. This forms the rationale for this study. Relevant meta-analyses reviewed the relation between leadership styles or school leaders' behaviors and teachers' job satisfaction as a subcategory or an additional variable of the study. In their meta-analysis Aydin, Sarier, and Uysal (2013) studied the effect of school leaders' leadership styles on organizational commitment and teacher job satisfaction in terms of a full-range leadership model. Another meta-analysis by Sarier (2013) focused on the relation between school principals' leadership styles and school outputs. Çoğaltay, Karadağ, and Öztekin (2014) reviewed the effect of school principals' transformational leadership behaviors on teachers' organizational commitment meta-analytically. Çoğaltay and Karadağ (2016) studied the effect of educational leadership on some organizational variables including job satisfaction in Turkey meta-analytically. The metaanalysis conducted by Çoğaltay, Yalçın, and Karadağ (2016) reviewed the correlation of educational leadership and teacher job satisfaction based on studies published between 2000 and 2016 in Turkey. The current metaanalysis is also a correlational meta-analysis of school leadership styles and teachers' job satisfaction based on the studies published between 2010 and 2020 in Turkey. Another distinction of the current and other study cited concerns the full range of leadership behaviors and MLQ in the review.

Numerous meta-analyses have been conducted on school leadership styles and school outputs including teachers' job satisfaction on the international level. A sample of studies conducted as systematic reviews or meta-analyses are cited here to make a comparison. The meta-analysis conducted by Chin (2007) is a study that reviews the effects of transformational school leadership on school outcomes in Taiwan and the USA. In another meta-analysis, Lowe, Kroeck, and Sivasubramaniam (1996) studied the effectiveness of transformational and transactional leadership by reviewing the literature on MLQ. Judge and Piccolo (2004) tested the validity of transformational and transactional leadership meta-analytically. A meta-analysis of the relationships between different leadership practices and organizational, teaming, leader, and employee outcomes, including job satisfaction, was conducted by Dunst, Bruder, Hamby, Howse, and Wilkie (2018).

\section{Purpose}

The aim of this study is to determine the correlational effect of full-range leadership model on teachers' job satisfaction meta-analytically. To this end, empirical data have been gathered from relevant studies to determine an overall effect size. Performing a meta-analysis, similar statistical data from similar studies were compiled to obtain an aggregate statistical data for effect size. Based on this aim, the following hypotheses were tested:

H1: The correlational effect of transformational school leadership on teachers' job satisfaction is higher than any other leadership style.

H2: The correlational effect of transactional school leadership on teachers' job satisfaction is positive.

H3: The correlational effect of laissez-faire school leadership on teachers' job satisfaction is lower than any other leadership style. 


\section{Methodology}

The method followed in the current study is a systematic research synthesis known as meta-analysis. A meta-analysis, in a nutshell, is a method of combining, integrating, summarizing, and reinterpreting sets of selected scholarly studies in several fields (Lipsey \& Wilson, 2001). The core concept of a meta-analysis is the effect size. Effect size is a statistical value that represents the effect of a variable on a treatment group by comparing a control group or a correlational value that shows the relation between two variables. In this study, the effect of leadership style on job satisfaction calculated by using Fisher 's Z values. Then it was converted into Pearson correlation coefficients (r) to make interpretations. According to the classification of Lipsey \& Wilson (2001), the effect size of correlational levels is interpreted by using the following thresholds:

$0<\mathrm{r} \leq 0.10$ small effect

$0.10<\mathrm{r}<0.40$ medium effect

$r \geq 0.40$ large effect

In this meta-analysis, correlational studies analyzing the effects of leadership styles on teachers' job satisfaction were reviewed. The common goal of the studies included was to determine the correlation between school principals' leadership styles and teachers' job satisfaction. The measurement tools or scales used in the studies are almost the same. The leadership qualifications were determined by the Multifactor Leadership Questionnaire (MLQ), whereas job satisfaction levels were determined by Minnesota Satisfaction Questionnaire (MSQ). The majority of the studies used both of these instruments. Whereas studies using MLQ and/or MSQ were included in the analysis and those studies that used neither of them were excluded.

\section{Data Collection, Inclusion Criteria and Coding Process}

The following inclusion criteria were used to determine which studies were to be included in the metaanalysis.

1. Studies conducted between January 01, 2010 and June 30, 2020.

2. Studies conducted in Turkey.

3. Studies in the form of articles or theses.

4. Studies having correlational statistics (r) and sample size (n).

5. Studies using either MLQ or MSQ as a scale.

6. Studies published in Turkish or English.

Since this study focuses on Turkish school principals' leadership styles and teachers' job satisfaction levels, studies conducted in Turkey were selected. Data gathered from Turkish educational institutions were analyzed. Three leadership styles derived from the MLQ scale (i.e., transformational, transactional and laissezfaire) were taken into account. MSQ was used to determine job satisfaction levels. The majority of the selected studies use both of these instruments. Studies incorporating only one of these scales include correlational data comparing leadership style and job satisfaction. When studies were repeated as an article or thesis, theses were selected for analysis. After applying the inclusion criteria, 11 theses, 4 articles, and 15 studies were analyzed. These studies have similar statistical data and research design.

In this study doctoral theses, master's theses and papers published in refereed journals are taken into consideration as the type of publication to be included. In order to determine the researches to be included in the study first of all, a literature review was made in YOK (Council of Higher Education in Turkey) National Thesis Center, ULAKBIM (Turkish Academic Network and Information Center) National Academic Network, and Google Scholar databases were searched to identify all the studies related to the research problem. In the first step, search was made by using the statements "school leadership style, teachers' job satisfaction, leadership, job satisfaction". There were 1739 theses on National Thesis Center's site, 1794 articles and theses 
on National Academic Network's site and 1930 theses, books, book reviews, papers and articles on Google Academic. In the first screening the books, book reviews, papers and repeated items were eliminated. There were 688 theses on National Thesis Center, 108 articles and theses on National Academic Network and 105 articles and theses on Google Academic left. After the second elimination by applying the inclusion criteria more detailed the search resulted in 29 studies being found in the National Thesis Center and 21 studies being found in the National Academic Network and 23 items on Google Academic. At the last stage of elimination, the repeated studies, the studies have not MLQ or MSQ scales eliminated. Finally, 11 theses from National Thesis Center, 1 article from National Academic Network and 3 articles from Google Academic thus, 15 studies included in the analysis by applying all the inclusion criteria. The studies eligible to the inclusion criteria selected by also reviewing the statistical data suitable to calculate the effect size metric.

The studies included in the meta-analysis were coded by publication year and type, statistical data, leadership style and job satisfaction scales, sample sizes, and school levels. After the author coded all of the studies, a doctorate student performed a second coding process. Coding agreement was then checked, resulting in an intercoder reliability of $95 \%$.

\section{Data Analysis}

As a correlational meta-analysis, leadership styles' effect on job satisfaction was determined by combining the correlation coefficients of all related studies. Each study contains a correlation coefficient for leadership style and job satisfaction, which were each accepted as an analysis unit. The effect of transformational, transactional, and laissez-faire leadership styles on job satisfaction was each calculated separately. Both SPSS and CMA were used to conduct and illustrate statistical calculations.

The entire collection of studies was carefully combed through to identify which used correlation coefficients and which used a different data format. If there was a single correlation between a specific leadership style and job satisfaction, that value was taken as the correlation to be combined. If correlation coefficients were given for sub-scales of a specific leadership style or job satisfaction, the mean of all correlations was taken instead. Methods of correcting the average correlations are various; however, most of these methods can result in high correlation estimates (Schyns \& Schilling, 2013). A conservative estimation was used as the average correlation which creates a conservative estimation of the entire correlation in this study. For instance, if in a study the correlation between the five sub-scales of transformational leadership and job satisfaction, the sum of all the correlations was divided by five to obtain a mean correlation. If a study provided the correlations for intrinsic and extrinsic job satisfaction of a specific leadership style, the sum of the correlations was divided by two. Total effect sizes, forest plots, heterogeneity analyses, publication bias tests, and moderator analysis were made for each leadership style and then interpreted.

Describing the degree of a correlation or the ratio of the difference between experimental and control means and the standard deviation, effect size is one of the fundamental calculations made in meta-analyses. There are two types of effect size calculations: fixed effect and random effect models. In fixed models, it is assumed that all effect sizes are computed from the same sample whereas in random model, it is accepted that all effect sizes are computed from different samples (Borenstein, Hedges, Higgins, \& Rothstein, 2009). Since the samples in the study are all different, it was decided to employ a random-effect model to calculate effect sizes. Sub-categorical analyses for publication bias (i.e., funnel plot, Orwin and Rosenthal fail-safe number, Egger's test, Begg and Mazumdar's test, Duval and Tweedie trim and fill test) were likewise performed for each case in accordance to the random model. The only exceptional analysis made was Orwin's fail safe number analysis. The software used to perform the analyses was set to make calculations for fixed-effect models. This does not affect the overall means and results of the study it simply supplies the number of studies needed to bring the calculated effect size value to a critical value. 


\section{Findings}

The meta-analytic findings on leadership styles and job satisfaction are depicted in figures and tables. The correlational effect sizes of leadership style and job satisfaction were calculated in a random effect model. The calculations made for job satisfaction and for each leadership style were checked to determine whether the distributions of effect sizes were affected by publication bias, heterogeneity, and moderators. Following these audits, we checked the findings for hypotheses. Correlational effect size statistics were revisited for each hypothesis. Effect sizes' thresholds determined the correlation level between that leadership style and job satisfaction. In-depth interpretation of the findings is included in the discussion and results sections. Metaanalytical statistics were compared to the statistics of previous studies conducted in similar fields. Although this study is not a replication of any previous study, the statistical results of the most similar studies were checked and meta-analytical results interpreted. Especially findings of the similar studies reviewed to make comparisons of the effect sizes. Findings of the correlational studies were also checked to make comparisons between the impact of leadership styles on teachers' job satisfaction.

Findings for Transformational Leadership and Job Satisfaction

Effect Sizes and Forest Plot

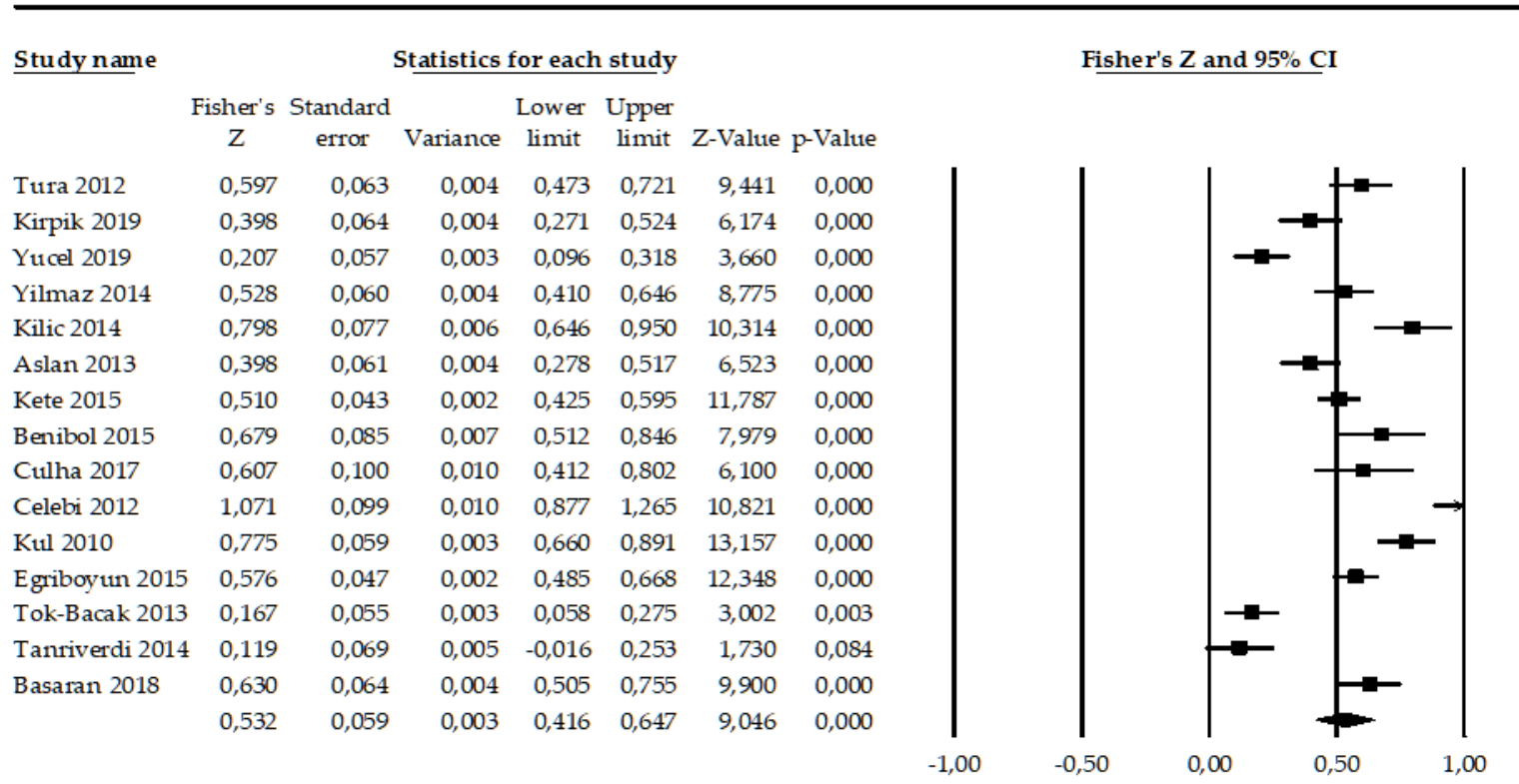

Transformational Leadership and Job Satisfaction

Figure 1. Meta-analytic statistics of transformational leadership and job satisfaction.

As for the relationship between transformational leadership and job satisfaction, the correlational effect sizes and forest plot depicted in Figure 1 shows that effect size distributions vary between 0.119 and 1.071 . The overall effect size calculated in the random model and in terms of Fisher's $Z$ values is 0.532 , and that the confidence interval of effect sizes' distribution is $95 \%$ at $\mathrm{p}<0.05$. 
Table 1. Effect of Transformational Leadership on Job Satisfaction and Heterogeneity Statistics

\begin{tabular}{|c|c|c|c|c|c|c|c|c|c|c|}
\hline \multirow{2}{*}{ Model } & \multicolumn{4}{|c|}{ Effect Sizes and 95\% Interval } & \multicolumn{2}{|c|}{$\begin{array}{l}\text { Null Hypothesis } \\
\text { Test (Two-Tailed) }\end{array}$} & \multicolumn{4}{|c|}{ Heterogeneity } \\
\hline & $\begin{array}{l}\text { Number } \\
\text { of studies }\end{array}$ & $\begin{array}{c}\text { Point } \\
\text { estimate }\end{array}$ & $\begin{array}{l}\text { Lower } \\
\text { limit }\end{array}$ & $\begin{array}{l}\text { Upper } \\
\text { limit }\end{array}$ & $\mathbf{Z}$ & p & Q & $\operatorname{df}(Q)$ & p & $\mathbf{I}^{2}$ \\
\hline \multirow[t]{2}{*}{ Fixed } & 15 & 0.461 & 0.436 & 0.485 & 3.220 & 0.000 & & & & \\
\hline & & & & & & & 184.391 & 14 & 0.000 & 92.407 \\
\hline Random & 15 & 0.487 & 0.394 & 0.570 & 9.046 & 0.000 & & & & \\
\hline
\end{tabular}

Table 1 illustrates that there is a positive correlation between transformational leadership and job satisfaction. The effect of leadership style on job satisfaction is calculated by using Fisher 's $Z$ values. Then it was converted into Pearson correlation coefficients ( $r$ ) to make interpretations. The effect of transformational leadership on job satisfaction in the random model and in terms of Pearson correlation coefficient is $r=0.487$, indicating a large effect size. The null hypothesis test shows there to be a significant correlation between transformational leadership and job satisfaction $(\mathrm{p}<0.05)$. Heterogeneity statistics denote the amount of variance observed in the studies. Although an $\mathrm{I}^{2}$ value of 92.407 means that the ratio of observed variance to the real variance is very high, it is not the only evidence of heterogeneity. The prediction power of intervals and the disparity of effect sizes among studies confirm there to be heterogeneity, thereby requiring moderator analyses to be conducted.

\section{Publication Bias Analyses}

In the process of bias analysis funnel plot, trim and fill, fail-safe numbers, and some other special tests developed for meta-analyses are used to test for publication bias in the findings. The statistics of each test were assessed in accordance to that test's own rules. The result of tests determines whether the effect sizes of the analyses are biased or not.

Funnel Plot of Standard Error by Fisher's Z

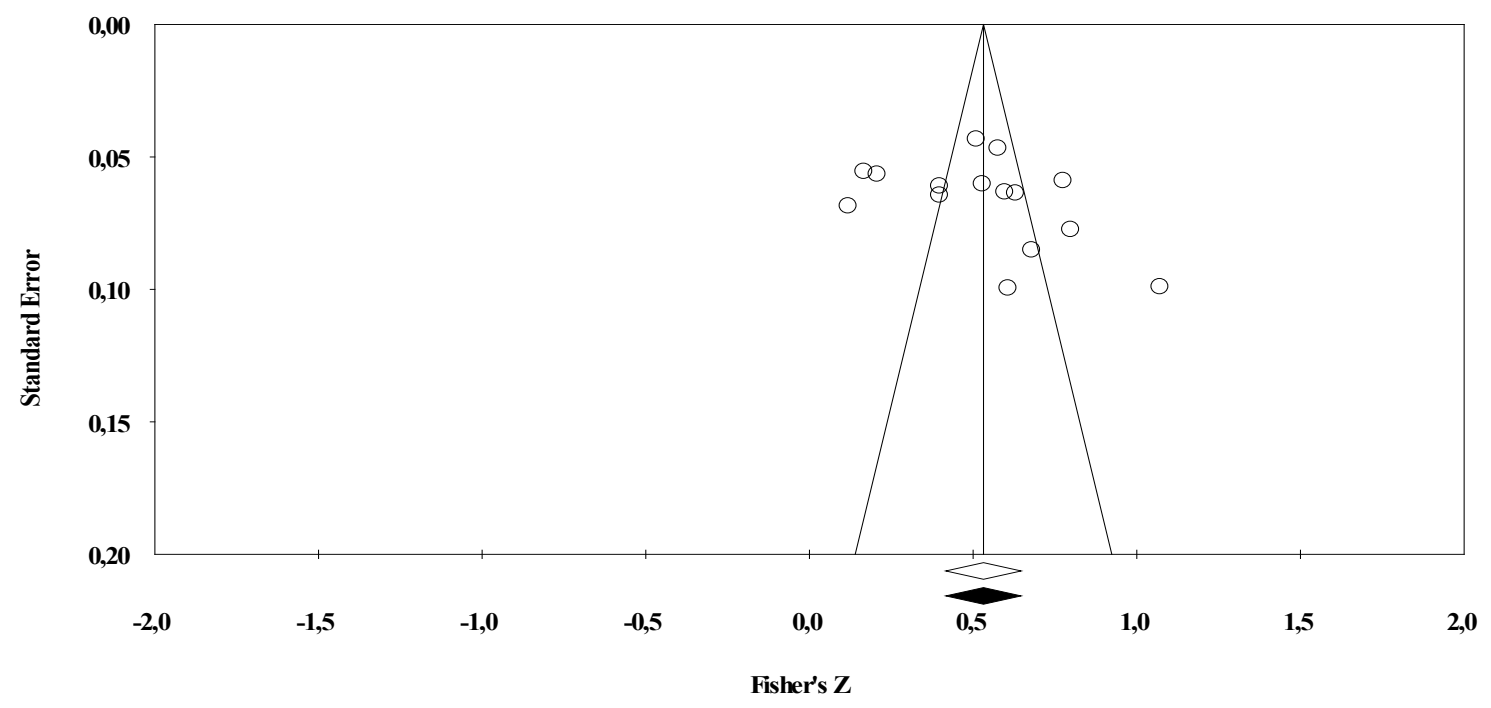

Figure 2. Funnel plot for transformational leadership and job satisfaction.

Figure 2 depicts the funnel plot of the effect sizes in terms of Fisher's $Z$ values and standard error. The plot shows that no study was missed so as to fix the bias. It is depicted by one white and black diamond. If it were any bias, missing studies would be denoted by black dots and the diamonds would not be in line (Üstün \& Eryılmaz, 2014). The results of this analysis shows that there are no black dots and the diamonds are abreast. 
Duval and Tweedie's trim and fill test applied for the bias as well. The results of Duval and Tweedie's trim-and-fill test shoved that there was not any trimmed and filled study to fix the bias. Had there been any bias, there would be adjusted values. Another bias test in the study is Begg and Mazumdar's rank-correlation test. In this test, the values of Tau and p were checked to ascertain whether the data were biased. A significant value of a one-tailed $\mathrm{p}$ indicates the possibility of publication bias. Results of the Tau value is 0.267 and $\mathrm{p}=$ 0.083, which is not significant at 0.05 level. Egger's test for bias applied to the data as well. According to the results, the standard error is 4.205 , the $t$ value is 1.204 , and the one-tailed $p$ is 0.119 . The significance of $p$ is taken into consideration for bias in this test. And the value of $\mathrm{p}$ was insignificant at level of 0.05 . One more type of bias test in the study was fail safe number test. The results of Rosenthal's fail-safe number test checked. The significance level and $Z$ value are 0.05 and 1.96 respectively. There should be 3842 missing studies so that p (0.000) will be greater than 0.05 . This means that at least 3842 studies with null effect are required to nullify the effect sizes calculated in this meta-analysis. But this figure greatly exceeds the number of studies analyzed. Another fail safe number test was Orwin's test. The effect size (calculated in fixed model) in this study is 0.461. The trivial criterion determined for the current study is 0.01 and the mean correlation of missing studies is 0.000. These statistics show that there must be 733 studies with a mean correlation of 0.000 to reduce the effect size from 0.461 to the trivial level of 0.01 . This number is significantly greater than the total number of studies included in the analysis.

\section{Moderator Analysis}

Table 2 presents the findings of the moderator variables for transformational leadership and job satisfaction. The three main moderators are publication type, school level, and the region in Turkey where the study was conducted. The statistics for the moderator analysis were evaluated at a significance level $p=0.05$.

Table 2. Moderator Analysis for Transformational Leadership and Job Satisfaction

\begin{tabular}{|c|c|c|c|c|c|c|c|}
\hline Moderator & Groups & $\mathbf{n}$ & $\mathbf{r}$ & $\begin{array}{c}\text { Lower } \\
\text { limit }\end{array}$ & $\begin{array}{c}\text { Upper } \\
\text { limit }\end{array}$ & $\mathbf{Z}$ & $\mathrm{p}$ \\
\hline \multirow{3}{*}{ Publication type } & Articles & 4 & 0.358 & 0.117 & 0.559 & 2.856 & 0.004 \\
\hline & Theses & 11 & 0.530 & 0.433 & 0.614 & 9.206 & 0.000 \\
\hline & Overall & 15 & 0.499 & 0.410 & 0.579 & 9.525 & $0.000^{*}$ \\
\hline \multirow{3}{*}{ Level } & Preschool & 4 & 0.420 & 0.123 & 0.648 & 2.710 & 0.007 \\
\hline & Primary & 11 & 0.509 & 0.418 & 0.590 & 9.470 & 0.000 \\
\hline & Overall & 15 & 0.499 & 0.413 & 0.577 & 9.829 & $0.000^{*}$ \\
\hline \multirow{5}{*}{ Region } & Aegean & 3 & 0.425 & 0.151 & 0.638 & 2.949 & 0.003 \\
\hline & Southeastern & 3 & 0.357 & 0.190 & 0.504 & 4.039 & 0.000 \\
\hline & Marmara & 6 & 0.528 & 0.368 & 0.657 & 5.731 & 0.000 \\
\hline & Other & 3 & 0.586 & 0.351 & 0.751 & 4.312 & 0.000 \\
\hline & Overall & 15 & 0.459 & 0.364 & 0.544 & 8.518 & $0.000^{*}$ \\
\hline
\end{tabular}

The results of the moderator analyses depicted in Table 2 shows that the variation in the effect size by publication type, school level, and region is significant $(\mathrm{p}<0.05)$. The effect size of articles is 0.358 , that of theses is 0.530 , and the overall effect size for all types of publications is 0.499 . The effect size for preschool is 0.420 , that for primary school is 0.509 , and the overall effect size for both school levels is 0.499 . The effect size for the Aegean region is 0.425, that for the Southeastern region is 0.357, that for the Marmara region is 0.528, that for the other regions is 0.586 , and the overall effect size for all regions is 0.459 . 
Findings for Transactional Leadership and Job Satisfaction

Effect Sizes and Forest Plot

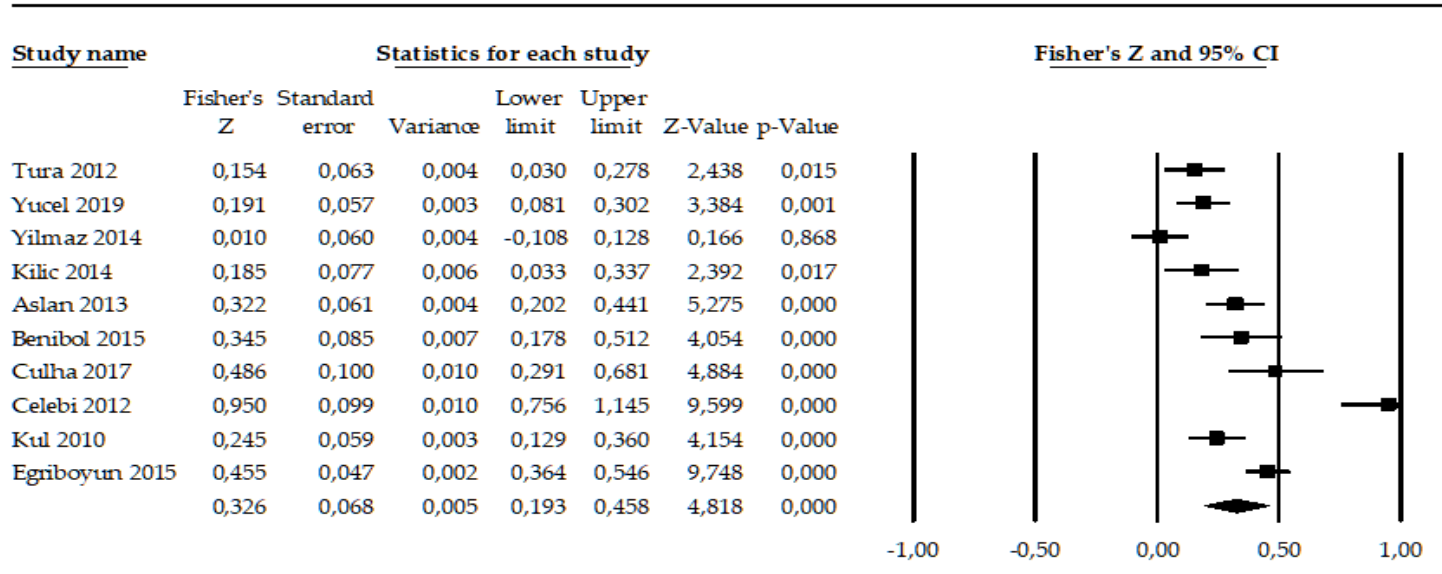

Trnasactional Leadership and Job Satisfaction

Figure 3. Meta-analytic statistics for transactional leadership and job satisfaction.

Figure 3 depicts the correlational effect sizes and forest plot of transactional leadership style and job satisfaction. Distributions of the effect sizes range between 0.010 and 0.950 . The overall effect size calculated in the random model in terms of Fisher's $\mathrm{Z}$ value is 0.326 . The confidence interval of the effect sizes' distribution is $95 \%$ at $\mathrm{p}<0.05$.

Table 3. Effect of Transactional Leadership on Job Satisfaction and Heterogeneity Statistics

\begin{tabular}{|c|c|c|c|c|c|c|c|c|c|c|}
\hline \multirow{2}{*}{ Model } & \multicolumn{4}{|c|}{ Effect Sizes and $95 \%$ Interval } & \multicolumn{2}{|c|}{$\begin{array}{l}\text { Null Hypothesis } \\
\text { Test (Two-Tailed) }\end{array}$} & \multicolumn{4}{|c|}{ Heterogeneity } \\
\hline & $\begin{array}{c}\text { Number } \\
\text { studies }\end{array}$ & $\begin{array}{c}\text { Point } \\
\text { estimate }\end{array}$ & $\begin{array}{c}\text { Lower } \\
\text { limit }\end{array}$ & $\begin{array}{c}\text { Upper } \\
\text { limit }\end{array}$ & $\mathbf{Z}$ & $\mathbf{P}$ & $\mathbf{Q}$ & $\operatorname{df}(Q)$ & $\mathbf{P}$ & $\mathbf{I}^{2}$ \\
\hline Fixed & 10 & 0.285 & 0.247 & 0.321 & 14.228 & 0.000 & & & & \\
\hline Random & 10 & 0.315 & 0.191 & 0.429 & 4.818 & 0.000 & 93.266 & 9 & 0.000 & 90.350 \\
\hline
\end{tabular}

As seen in Table 3, there is a positive correlation between transactional leadership and job satisfaction. The effect of leadership style on job satisfaction is calculated by using Fisher 's Z values. Then it was converted into Pearson correlation coefficients (r) to make interpretations. The effect of transactional leadership on job satisfaction in the random model is moderate, at $r=0.315$. The null hypothesis test shows that there is a significant correlation between transactional leadership and job satisfaction $(p<0.05)$. Moreover, heterogeneity statistics demonstrate the variance of studies. Although an $\mathrm{I}^{2}$ value of 90.350 means that the ratio of observed to real variance is quite high, it is not the only evidence of heterogeneity. The prediction power of intervals and variability of effect sizes between studies establishes that there is heterogeneity, which then requires moderator analyses to be conducted. 


\section{Funnel Plot of Standard Error by Fisher's Z}

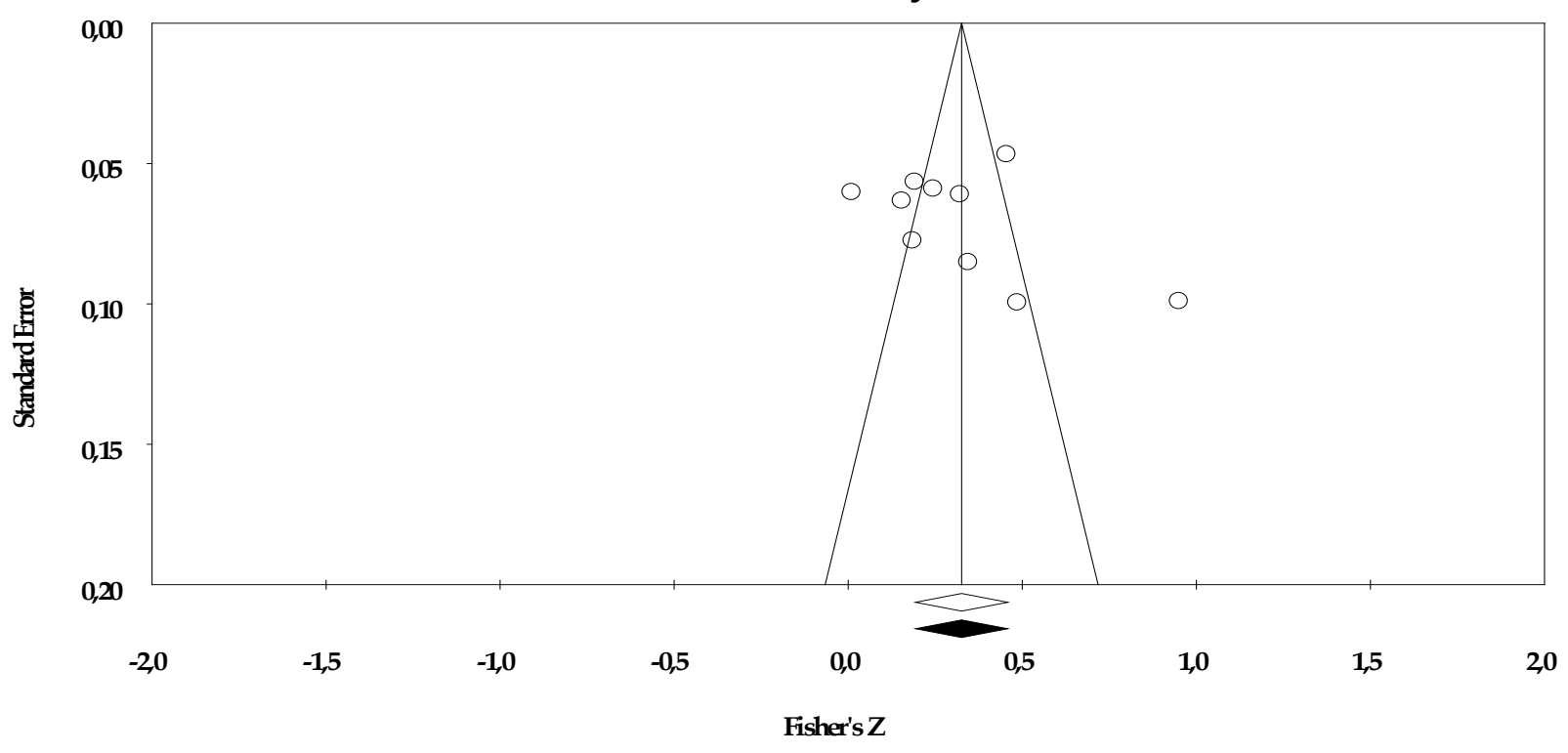

Figure 4. Funnel plot of transactional leadership and job satisfaction.

Figure 4 depicts the funnel plot of the effect sizes in terms of Fisher's $Z$ values and standard error. The plot shows that no study was missed study to fix the bias. Had there been any bias, the missing studies would have been denoted by black dots and the diamonds would not have been in line (Üstün \& Eryllmaz, 2014). The results of this analysis shows that there are no black dots and the diamonds are abreast.

Another bias test is Duval and Tweedie's trim-and-fill test. The effect size is calculated in a random model. The results prove that no study was trimmed and filled to fix the bias. Had there been any bias, there would have been adjusted values. Begg and Mazumdar's rank-correlation bias test was applied as well. In this test, Tau and $p$ values were checked to ascertain whether the data were biased. A significant value of onetailed $p$ indicates the possibility of publication bias. Tau value is 0.267 and $p=0.142$, which is not significant at level of 0.05. One more type of bias test is Egger's test. According to the results, the standard error is 4.506, the $t$ value is 0.984 , and the one-tailed $p$ is 0.177 . The significance of $p$ is taken into consideration for bias in this test. The value of $p$ is insignificant at the level of $p=0.05$. There were also fail-safe number calculations for bias in the study. Rosenthal's fail-safe number test. The significance level $\alpha$ and $\mathrm{Z}$ value for $\alpha$ are 0.05 and 1.96, respectively. There must be 544 missing studies for the $\mathrm{p}$ value $(0.000)$ to be greater than $\alpha$ level. This means that at least 544 studies with null effect to nullify the effect sizes calculated in this meta-analysis. But this number required is significantly greater than the total 10 studies analyzed. The other fail-safe number test is Orwin's test. The effect size calculated in the fixed model in this study is 0.285 . The trivial criterion determined for the current study is 0.01 and the mean correlation for missing studies is 0.000 . These statistics show that 283 studies with a mean correlation of 0.000 are required to reduce the effect size from 0.285 to the trivial level of 0.01 . Again, this number is highly greater than the total number of studies.

\section{Moderator Analyses}

Table 4 presents the findings of the moderator variables for transactional leadership and job satisfaction. The two main moderators are school level and the region in Turkey where the study was conducted. The statistics for the moderator analysis were evaluated at a significance level of $\mathrm{p}=0.05$. 
Table 4. Moderator Analysis for Transactional Leadership and Job Satisfaction

\begin{tabular}{llcccccc}
\hline \multirow{2}{*}{ Moderator } & Groups & $\mathbf{n}$ & $\mathbf{r}$ & $\begin{array}{c}\text { Lower } \\
\text { limit }\end{array}$ & $\begin{array}{c}\text { Upper } \\
\text { limit }\end{array}$ & $\mathbf{Z}$ & $\mathbf{p}$ \\
\hline \multirow{3}{*}{ Level } & Preschool & 3 & 0.224 & 0.135 & 0.309 & 4.854 & 0.000 \\
\cline { 2 - 8 } & Primary & 7 & 0.350 & 0.181 & 0.499 & 3.916 & 0.000 \\
\cline { 2 - 8 } & Overall & $\mathbf{1 0}$ & $\mathbf{0 . 2 5 0}$ & $\mathbf{0 . 1 7 2}$ & $\mathbf{0 . 3 2 6}$ & $\mathbf{6 . 0 9 6}$ & $\mathbf{0 . 0 0 0 *}$ \\
\hline \multirow{3}{*}{ Region } & Marmara & 4 & 0.246 & 0.131 & 0.355 & 4.129 & 0.000 \\
\cline { 2 - 8 } & Other & 6 & 0.355 & 0.164 & 0.520 & 3.544 & 0.000 \\
\cline { 2 - 8 } & Overall & $\mathbf{1 5}$ & $\mathbf{0 . 2 7 5}$ & $\mathbf{0 . 1 7 7}$ & $\mathbf{0 . 2 6 7}$ & $\mathbf{5 . 3 5 2}$ & $\mathbf{0 . 0 0 0 *}$ \\
\hline
\end{tabular}

The statistics for the moderator analyses shown in Table 4 demonstrates that variation in the effect sizes by school level and region is significant $(p<0.05)$. The effect size for preschools is 0.224 , that of primary schools is 0.350 , and the overall effect size for both school levels is 0.250 . The effect size for the Marmara region is 0.246 , that for other regions is 0.355 , and the overall effect size for all regions is 0.275 .

Findings for Laissez-faire Leadership and Job Satisfaction

\section{Effect Sizes and Forest Plot}

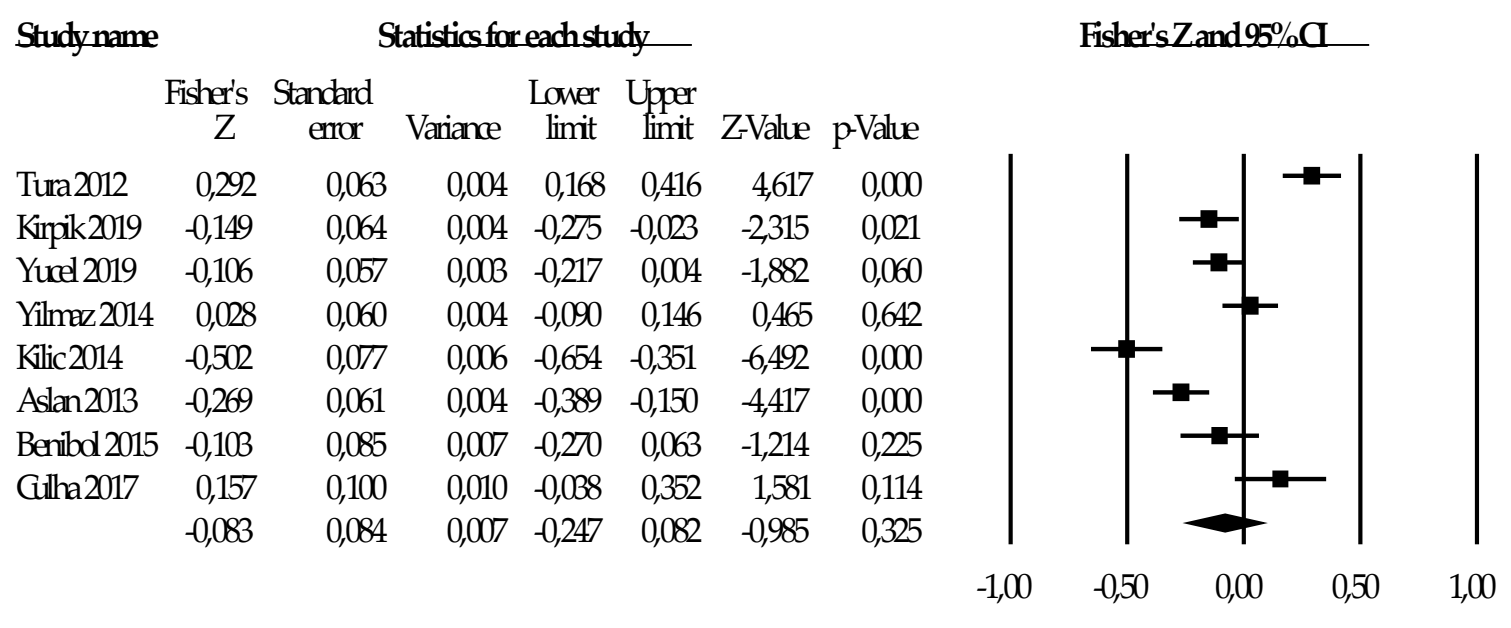

\section{Laissez-faire Leadershipand Job Satisfaction}

Figure 5. Meta-analytic statistics of laissez- faire leadership and job satisfaction.

Figure 5 depicts the correlational effect sizes and forest plot for laissez-faire leadership and job satisfaction in terms of Fisher's Z values. Distributions of the effect sizes range between -0.502 and 0.292 . The overall effect size calculated in the random model is -0.083 . There is a negative correlation between laissezfaire leadership and job satisfaction. The confidence interval of the effect sizes' distribution is $95 \%$ at $\mathrm{p}<0.05$. 
Table 5. Effect of Laissez-faire Leadership on Job Satisfaction and Heterogeneity Statistics

\begin{tabular}{|c|c|c|c|c|c|c|c|c|c|c|}
\hline \multirow{2}{*}{ Model } & \multicolumn{4}{|c|}{ Effect Sizes and $95 \%$ Interval } & \multicolumn{2}{|c|}{$\begin{array}{l}\text { Null Hypothesis } \\
\text { Test (Two-Tailed) }\end{array}$} & \multicolumn{4}{|c|}{ Heterogeneity } \\
\hline & $\begin{array}{c}\text { Number } \\
\text { studies }\end{array}$ & $\begin{array}{c}\text { Point } \\
\text { estimate }\end{array}$ & $\begin{array}{c}\text { Lower } \\
\text { limit }\end{array}$ & $\begin{array}{l}\text { Upper } \\
\text { limit }\end{array}$ & $\mathrm{Z}$ & $\mathbf{P}$ & $\mathbf{Q}$ & $\mathrm{df}(\mathrm{Q})$ & $\mathbf{p}$ & $I^{2}$ \\
\hline \multirow[t]{2}{*}{ Fixed } & 8 & -0.081 & -0.128 & -0.035 & -3.419 & 0.001 & & & & \\
\hline & & & & & & & 84.385 & 7 & 0.000 & 91.705 \\
\hline Random & 8 & -0.082 & -0.242 & 0.082 & -0.985 & 0.325 & & & & \\
\hline
\end{tabular}

It is seen in Table 5, there is a negative correlation between laissez-faire leadership and job satisfaction. The effect of leadership style on job satisfaction is calculated by using Fisher 's Z values. Then it was converted into Pearson correlation coefficients ( $r$ ) to make interpretations. There is a small, negative correlation between laissez-faire leadership and job satisfaction $(\mathrm{r}=-0.082)$. The null hypothesis test shows that there is a significant relation between laissez-faire leadership style and job satisfaction $(\mathrm{p}<0.05)$. Statistics of heterogeneity denotes the variance of studies. Although the $\mathrm{I}^{2}$ value of 91.705 obtained demonstrates that the ratio of observed to real variance is very high, it is not the only evidence for heterogeneity. The prediction power of intervals and variability of effect sizes between studies establishes that there is heterogeneity, which then requires moderator analyses to be conducted.

Publication Bias Analyses

\section{Funnel Plot of Standard Error by Fisher's Z}

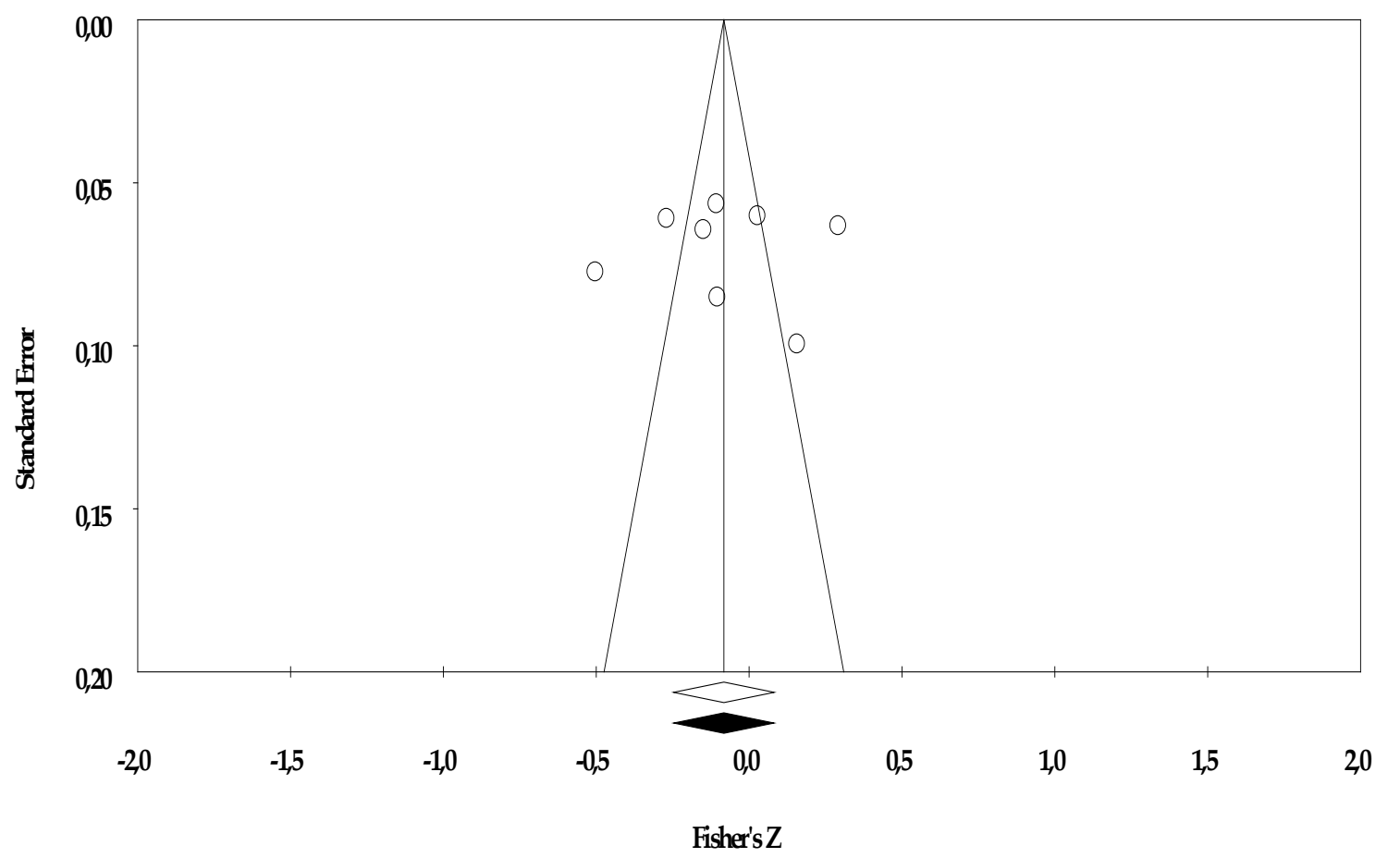

Figure 6. Funnel plot of laissez-faire leadership and job satisfaction.

Figure 6 depicts the funnel plot for effect sizes in terms of Fisher's $Z$ values and standard error. The plot shows that no missed study was missed in order to fix the bias. If there had been any bias, missing studies would be denoted by black dots and the diamonds would not be the diamonds would not have been in line 
(Üstün \& Eryllmaz, 2014). The results of this analysis shows that there are no black dots and the diamonds are abreast.

Another bias test applied in the study is Duval and Tweedie's trim-and-fill test. The effect size is calculated in a random model. The results demonstrate that no study was trimmed and filled to fix any bias. Had there been any bias, there would be adjusted values. The other bias test in the study is Begg and Mazumdar's rank-correlation test. In this test, Tau and $\mathrm{p}$ values were checked to ascertain the bias. A significant value of a one-tailed $\mathrm{p}$ indicates the possibility of publication bias. According to the results, Tau value is 0.036 and $p=0.451$. This value is not significant at the level of 0.05 . Egger's test applied for bias as well. The calculated standard error is 7.787 , the $t$ value is 0.071 , and the one-tailed $p$ is 0.473 . The significance of $p$ is taken into consideration for bias in this test. As a result, the value of $p=0.473$ is non-significant at the level of 0.05 .

As a fail-safe number, Rosenthal's fail-safe number test is applied. Significance level and $\mathrm{Z}$ value are 0.05 and 1.96 respectively. According to the result, there should be 17 missing studies so that $p(0.001)$ will be greater than 0.05 . This means that at least 17 studies with null effect are required to nullify the effect sizes calculated in this meta-analysis. But this figure is more than double the total number of studies analyzed. The other fail-safe number test is Orwin's test. The effect size (calculated in a fixed model) in this study is -0.081 . The trivial criterion determined for the study is -0.01 and the mean correlation of missing studies is 0.000 . These statistics show that there must be 58 studies with a mean correlation of 0.000 to increase the effect size from -0.081 to the trivial level of 0.01 . This number is also greater than the total number of studies.

\section{Moderator Analyses}

Table 21 presents the findings of the moderator variables for laissez-faire leadership and job satisfaction. The two main moderators are school level and the region in Turkey where the study was conducted. The statistics for the moderator analysis were evaluated at the significance level of $\mathrm{p}=0.05$.

Table 6. Moderator Analysis for Laissez-faire Leadership Style and Job Satisfaction

\begin{tabular}{llllllll}
\hline \multirow{2}{*}{ Moderator } & Groups & $\mathbf{n}$ & $\mathbf{r}$ & Lower limit & $\begin{array}{c}\text { Upper } \\
\text { limit }\end{array}$ & $\mathbf{Z}$ & $\mathbf{p}$ \\
\hline \multirow{3}{*}{ Level } & Preschool & 3 & -0.232 & -0.454 & 0.018 & -1.823 & 0.068 \\
\cline { 2 - 8 } & Primary & 5 & 0.009 & -0.195 & 0.211 & 0.083 & 0.934 \\
\cline { 2 - 8 } & Overall & $\mathbf{8}$ & $\mathbf{- 0 . 0 8 8}$ & $\mathbf{- 0 . 2 4 3}$ & $\mathbf{0 . 0 7 1}$ & $\mathbf{- 1 . 0 8 5}$ & $\mathbf{0 . 2 7 8}$ \\
\hline \multirow{3}{*}{ Region } & Marmara & 3 & -0.018 & -0.485 & 0.457 & -0.068 & 0.946 \\
\cline { 2 - 8 } & Other & 5 & -0.120 & -0.216 & -0.021 & -2.377 & 0.017 \\
\cline { 2 - 8 } & Overall & $\mathbf{8}$ & $\mathbf{- 0 . 1 1 6}$ & $\mathbf{- 0 . 2 1 1}$ & $\mathbf{- 0 . 0 1 9}$ & $\mathbf{- 2 . 3 4 6}$ & $\mathbf{0 . 0 1 9 *}$ \\
\hline
\end{tabular}

The results of the moderator analyses depicted in Table 6 shows that variation of the effect sizes by school level is not significant ( $p>0.05)$. Variance of the effect size by regions is, however, significant $(\mathrm{p}<0.05)$. The effect size for preschools is -0.232 , that of primary schools is 0.009 , and the overall effect size for both school level is -0.088 . Effect size for the Marmara region is -0.018 , that for other regions is -0.120 , and overall effect size for all region is -0.116 .

\section{Findings for the Hypotheses}

The results for leadership styles' effect on job satisfaction in terms of correlations are as follows: Transformational leadership's effect size on job satisfaction is large $(r=0.487)$. The effect size of transactional leadership on job satisfaction is moderate $(\mathrm{r}=0.315)$. The only leadership style with a negative effect on job satisfaction is the laissez-faire style of leadership is small $(r=-0.082)$. 
The findings reveal that transformational leadership has the greatest effect on teachers' job satisfaction, as verified by effect sizes. This result confirms the first hypothesis (H1) asserting that the correlational effect of transformational school leadership style on teachers' job satisfaction is higher than any other leadership style.

The comparisons made for effect sizes' magnitudes reveal that transactional leadership has the second largest effect on teachers' job satisfaction. Specifically, transactional leadership has a moderate, positive effect on job satisfaction. This result confirms the second hypothesis (H2) asserting that transactional school leadership has a positive effect on teachers' job satisfaction.

Laissez-faire leadership is the sole leadership style that has a negative effect on teachers' job satisfaction. The statistics empirically confirm this notion. Laissez-faire leadership has a small, negative effect on job satisfaction. The third hypothesis of the study (H3) asserting that the correlational effect of laissez-faire school leadership on teachers' job satisfaction is lower than any other leadership style was also confirmed.

\section{Discussions, Conclusions, and Suggestions}

The findings of this study show that school principals' leadership styles have an effect on teachers' job satisfaction levels. Regarding the components of a full-length leadership model, it is clear that transformational leadership has the greatest positive effect on teachers' job satisfaction followed by transactional leadership. The only leadership style with a negative effect on job satisfaction is laissez-faire leadership, which is the absence of leadership. The results agree with the findings of earlier studies. There is a common conviction in the literature that transformational leadership can motivate teachers and change their attitude for the better. Transactional leadership positively effects teachers and makes them feel content whereas laissez-faire leadership decreases teachers' satisfaction levels.

The meta-analysis conducted by Çoğaltay et al., (2016) reviewed the correlation between educational leadership and teacher job satisfaction. The studies included in the analysis were published in Turkey between the years 2000 and 2016. The current meta-analysis also reviews school leadership styles and teachers' job satisfaction during a different period, namely, from 2010 to 2020, in Turkey. According to the results of the preceding study, transformational leadership has strongest large effect $(0.520)$ on job satisfaction, the strongest of all leadership styles. The same result was found in the current meta-analysis, namely that the effect size is large $(r=0.487)$. Transformational leadership is the leadership style analyzed in both studies, and the results are similar. There are likewise similar subcategories analyzed as moderators in both studies, namely, publication type, school level, and region where the studies being analyzed were conducted. The results reached in both studies indicate that region is a moderator variable on the correlation between educational leadership and job satisfaction. The results of the cited study did not find the level and type of school to have a moderating role on job satisfaction. On the contrary, school level was determined to be statistically significant for transformational and transactional leadership style and not supported significantly for laissez-faire style in the current meta-analysis. Publication type has a significant moderating role on the effect sizes of leadership style and job satisfaction for transformational leadership in the current meta-analysis. On the other hand, publication type did not have a mediating role in either of the other two leadership styles in this study or the cited meta-analysis.

In the meta-analysis conducted by Aydın et al., (2013), the effect of school leaders' leadership style on organizational commitment and teacher job satisfaction was sought in terms of a full-range leadership model. Although the cited study found, using a fixed-effect model, that transformational leadership had a large effect (0.810) on job satisfaction, the current meta-analysis found it to be 0.487 . Whereas the study cited found transactional leadership to have a large effect (0.560) on job satisfaction, the same calculation resulted in a moderate effect $(0.315)$ in the current study. In both studies, there was a negative correlation between the 
laissez-faire leadership style and teachers' job satisfaction. The effect size of the current study is a small level $(-0.082)$ whereas the effect size of the cited study $(-0.150)$ was moderate.

Another meta-analysis by Sar1er (2013) focused on the correlation between school principals' leadership styles and school outputs, which include teachers' job satisfaction. The findings were similar to the results of the current meta-analysis for the relevant statistics. In the cited study, the correlational effect size of transformational leadership was large (0.650) whereas the effect size determined in the current meta-analysis is 0.487 . The transactional leadership was large $(0.420)$ whereas the current study found it to be moderate (0.315). In both studies, the correlational effect sizes for laissez-faire leadership were negative and small, -0.050 for the cited one and -0.082 for the current study.

A similar study published outside of Turkey conducted by Chin (2007) is a meta-analysis reviewing the effects of transformational school leadership on school outcomes in Taiwan and the USA. The common variables of the current meta-analysis and the cited study are transformational school leadership and job satisfaction. According to the results of the cited study, transformational leadership has a positive, significant, large effect $(r=0.707)$ on teacher job satisfaction. The correlational effect size of transformational leadership and job satisfaction of the current meta-analysis $(\mathrm{r}=0.487)$ is also positive and large.

In their meta-analytical study, Judge and Piccolo (2004) tested transformational and transactional leadership relative validity. The findings reveal positive correlations for transformational leadership $(\mathrm{r}=0.440)$ and transactional leadership $(r=0.390)$. and a negative correlation for laissez-faire leadership $(r=-0.370)$. These statistics partially confirm the results of the present study. The statistics of the current study support previous studies through positive and negative correlations between leadership styles and job satisfaction.

In conclusion, these findings are consistent with the results of other researchers (Avolio et al., 1999, Leithwood \& Jantzi, 1999; Leithwood, 1992) and proved that thoughtful educational leaders interested in teachers as individuals affect them positively. Proactive leaders produce positive results for teachers, such as teachers having higher job satisfaction levels and perceiving their schools to be more effective. These results make it clear that if school leaders wish to influence school outcomes, they should reevaluate their leadership style and endeavor to incorporate transformational and transactional leadership dimensions, as identified by the MLQ. Moreover, laissez-faire leadership behaviors should not be preferred by leaders. As Leithwood (1992) has indicated, transformational leadership behaviors help school leaders establish sustainable and constant innovations in their school. As concluded by Leithwood and Jantzi (1999), transformational school leaders working with teachers cooperatively can develop problem solving skills, strengthen organizational commitment, and make them contribute the common goals. These behaviors of transformational and transactional leadership styles consequently also lead teachers to feel more content about their job. Because transformational and transactional leadership styles are similar, it is difficult to make a clear distinction between their unique effects. This is an implication of the view supported by Bass (1985), which sees transformational and transactional leadership as two distinct, though not mutually exclusive processes.

Given the results of the present and other studies, some suggestions can be made for researchers and educational leaders, namely:

- Transformational and transactional leadership activities can be conducted through educational workshops.

- Having transactional leadership workshops will be beneficial for school leaders because transformational and transactional styles can be used interchangeably in some cases.

- School leaders should avoid performing no leadership behaviors, or, in other words, adopt laissez-faire leadership practices because it has negative effects on teachers' job satisfaction. 
- Meta-analyses reviewing the dimensions of transformational and transactional leadership styles in connection with teachers' job satisfaction can be conducted. 
APPENDIX 1: Data about the studies included in the meta-analysis

\begin{tabular}{|c|c|c|c|c|c|c|c|c|c|}
\hline \multicolumn{10}{|c|}{ Data of the Studies Included in the Meta-Analys is } \\
\hline No & Type & Year & Study Name & Level & Region & Variable & Correlation & Leadership & Scale \\
\hline 1 & Thesis & 2012 & $\begin{array}{l}\text { Tura, M.(2012).illköğretim okulu müdürlerinin } \\
\text { liderlik stillerinin öğretmenlerin iş doyumuna } \\
\text { etkisi: Karacabey ilçesi örneği. }\end{array}$ & Primary & Marmara & $\begin{array}{l}\text { Independent: } \\
\text { Leadership style } \\
\text { Dependent: } \\
\text { Job satisfaction } \\
\end{array}$ & $\begin{array}{l}\mathrm{r} 1=0,535 \\
\mathrm{r} 2=0,153 \\
\mathrm{r} 3=0,284 \\
\mathrm{~N}=253\end{array}$ & $\begin{array}{l}\text { Transformational } \\
\text { Transactional } \\
\text { Laissez faire }\end{array}$ & $\begin{array}{l}\text { MLQ } \\
\text { MSQ }\end{array}$ \\
\hline 2 & Thesis & 2019 & $\begin{array}{l}\text { Canpolat Kırpık, A.N.(2019). Okul yöneticilerinin } \\
\text { liderlik tarzları ile öğretmenleriniş doyumu } \\
\text { arasındaki ilişkinin incelenmesi. }\end{array}$ & Primary & Mediterranean & $\begin{array}{l}\text { Independent: } \\
\text { Leadership style } \\
\text { Dependent: } \\
\text { Job satisfaction } \\
\end{array}$ & $\begin{array}{l}\mathrm{r} 1=0,378 \\
\mathrm{r} 3=-0,148 \\
\mathrm{~N}=244\end{array}$ & $\begin{array}{l}\text { Transformational } \\
\text { Laissez faire }\end{array}$ & $\begin{array}{l}\text { MLQ } \\
\text { MSQ }\end{array}$ \\
\hline 3 & Thesis & 2019 & $\begin{array}{l}\text { Yücel Genç, B. (2019). Okul öncesi yöneticilerinin } \\
\text { liderlik stilleri ile öğretmenlerin iş doyumu } \\
\text { arasındaki ilişki. }\end{array}$ & Preschool & Southeastem & $\begin{array}{l}\text { Independent: } \\
\text { Leadership style } \\
\text { Dependent: } \\
\text { Job satisfaction } \\
\end{array}$ & $\begin{array}{l}\mathrm{r} 1=0,204 \\
\mathrm{r} 2=0,189 \\
\mathrm{r} 3=-0,106 \\
\mathrm{~N}=316\end{array}$ & $\begin{array}{l}\text { Transformational } \\
\text { Transactional } \\
\text { Laissez faire }\end{array}$ & $\begin{array}{l}\text { MLQ } \\
\text { MSQ }\end{array}$ \\
\hline 4 & Thesis & 2014 & $\begin{array}{l}\text { Y1lmaz, T.(2014). Özel okullardaki ilkokul } \\
\text { müdürlerinin liderlik biçimi ile sınıf } \\
\text { öğretmenlerinin iş doyumu arasındaki ilişki. }\end{array}$ & Primary & Aegean & $\begin{array}{l}\text { Independent: } \\
\text { Leadership style } \\
\text { Dependent: } \\
\text { Job satisfaction }\end{array}$ & $\begin{array}{l}\mathrm{r} 1=0,484 \\
\mathrm{r} 2=0,010 \\
\mathrm{r} 3=0,028 \\
\mathrm{~N}=279\end{array}$ & $\begin{array}{l}\text { Transformational } \\
\text { Transactional } \\
\text { Laissez faire }\end{array}$ & $\begin{array}{l}\text { MLQ } \\
\text { MSQ }\end{array}$ \\
\hline 5 & Thesis & 2014 & $\begin{array}{l}\text { Akyol Kilıç, M.(2014). Okul öncesi öğretmenlerin } \\
\text { yöneticilerinde algladıklan liderlik stilleri ile kendi } \\
\text { iș doyumu düzeyleri arasındaki ilişkinin } \\
\text { incelenmesi: İstanbul-Manila örneği. }\end{array}$ & i Preschool & Marmara & $\begin{array}{l}\text { Independent: } \\
\text { Leadership style } \\
\text { Dependent: } \\
\text { Job satisfaction } \\
\end{array}$ & $\begin{array}{l}\mathrm{r} 1=0,663 \\
\mathrm{r} 2=0,183 \\
\mathrm{r} 3=-0,464 \\
\mathrm{~N}=170\end{array}$ & $\begin{array}{l}\text { Transformational } \\
\text { Transactional } \\
\text { Laissez faire }\end{array}$ & $\begin{array}{l}\text { MLQ } \\
\text { MSQ }\end{array}$ \\
\hline 6 & Thesis & 2013 & $\begin{array}{l}\text { Aslan, Ü.(2013). Okul müdürlerinin liderlik stilleri } \\
\text { ile öğretmenleriniş̧ doyumu arasındaki iliş kinin } \\
\text { incelenmesi. }\end{array}$ & Primary & Southeastem & $\begin{array}{l}\text { Independent: } \\
\text { Leadership style } \\
\text { Dependent: } \\
\text { Job satisfaction } \\
\end{array}$ & $\begin{array}{l}\mathrm{r} 1=0,378 \\
\mathrm{r} 2=0,311 \\
\mathrm{r} 3=-0,263 \\
\mathrm{~N}=272\end{array}$ & $\begin{array}{l}\text { Transformational } \\
\text { Transactional } \\
\text { Laissez faire }\end{array}$ & $\begin{array}{l}\text { MLQ } \\
\text { MSQ }\end{array}$ \\
\hline 7 & Thesis & 2015 & $\begin{array}{l}\text { Kete, D.(2015). Okul müdürlerinin liderlik stilleri } \\
\text { ile öğretmenleriniș doyumu ve örgütsel adalet } \\
\text { alg1ları arasındaki ilișkinin incelenmesi. }\end{array}$ & Primary & Southeastem & $\begin{array}{l}\text { Independent: } \\
\text { Leadership style } \\
\text { Dependent: } \\
\text { Job satisfaction } \\
\end{array}$ & $\begin{array}{l}\mathrm{r} 1=0,470 \\
\mathrm{~N}=537\end{array}$ & Transformational & MSQ \\
\hline 8 & Thesis & 2015 & $\begin{array}{l}\text { Benibol, H.(2015). Okul öncesi eğitiminden } \\
\text { sorumlu müdürlerinin liderlik stillerinin } \\
\text { öğretmenlerin iș doyumu üzerine etkisi. }\end{array}$ & Preschool & Aegean & $\begin{array}{l}\text { Independent: } \\
\text { Leadership style } \\
\text { Dependent: } \\
\text { Job satisfaction } \\
\end{array}$ & $\begin{array}{l}\mathrm{r} 1=0,591 \\
\mathrm{r} 2=0,332 \\
\mathrm{r} 3=-0,103 \\
\mathrm{~N}=141\end{array}$ & $\begin{array}{l}\text { Transformational } \\
\text { Transactional } \\
\text { Laissez faire }\end{array}$ & $\begin{array}{l}\text { MLQ } \\
\text { MSQ }\end{array}$ \\
\hline 9 & Thesis & 2017 & $\begin{array}{l}\text { Çulha, Y.(2017). Okul psikolojik danışmanlarının } \\
\text { müdürlerinin liderlik stillerini algılamaları ile } \\
\text { kendi iş doyumu ve tükenmişlik düzeyleri } \\
\text { arasındaki ilişkinin incelenmesi. }\end{array}$ & Primary & Marmara & $\begin{array}{l}\text { Independent: } \\
\text { Leadership style } \\
\text { Dependent: } \\
\text { Job satisfaction } \\
\end{array}$ & $\begin{array}{l}\mathrm{r} 1=0,542 \\
\mathrm{r} 2=0,451 \\
\mathrm{r} 3=0,156 \\
\mathrm{~N}=104\end{array}$ & $\begin{array}{l}\text { Transformational } \\
\text { Transactional } \\
\text { Laissez faire }\end{array}$ & $\begin{array}{l}\text { MLQ } \\
\text { MSQ }\end{array}$ \\
\hline 10 & Thesis & 2012 & $\begin{array}{l}\text { Çelebi, C. (2012). İlköğretim okullannda görev } \\
\text { yapan okul müdürlerinin okulda gösterdikleri } \\
\text { liderlik stilleri ile öğretmenlerin iş doyumu } \\
\text { arasındaki ilişki. }\end{array}$ & Primary & Central Anatolia & $\begin{array}{l}\text { Independent: } \\
\text { Leadership style } \\
\text { Dependent: } \\
\text { Job satisfaction } \\
\end{array}$ & $\begin{array}{l}\mathrm{r} 1=0,790 \\
\mathrm{r} 2=0,740 \\
\mathrm{r} 3=0,029 \\
\mathrm{~N}=105\end{array}$ & $\begin{array}{l}\text { Transformational } \\
\text { Transactional } \\
\text { Laissez faire }\end{array}$ & MLQ \\
\hline 11 & Thesis & 2010 & $\begin{array}{l}\text { Kul, M.(2010). Okul yöneticilerinin liderlik stilleri } \\
\text { ile beden eğitimi öğretmenlerinin yllırma } \\
\text { (mobbing) yaşama düzeyleri, örgütsel bağllilılan } \\
\text { ve iş doyumu arasındaki ilişsi. }\end{array}$ & Primary & Marmara & $\begin{array}{l}\text { Independent: } \\
\text { Leadership style } \\
\text { Dependent: } \\
\text { Job satisfaction } \\
\end{array}$ & $\begin{array}{l}\mathrm{r} 1=0,650 \\
\mathrm{r} 2=0,240 \\
\mathrm{~N}=291\end{array}$ & $\begin{array}{l}\text { Transformational } \\
\text { Transactional }\end{array}$ & $\begin{array}{l}\text { MLQ } \\
\text { MSQ }\end{array}$ \\
\hline 12 & Article & 2015 & $\begin{array}{l}\text { Eğriboyun, D. (2015). Ortaöğretim okullannda } \\
\text { görev yapan yönetici ve öğretmenlerin liderlik } \\
\text { uygulamaları ve iș doyumu algılanı arasındaki ilișki. }\end{array}$ & Primary & Black Sea & $\begin{array}{l}\text { Independent: } \\
\text { Leadership style } \\
\text { Dependent: } \\
\text { Job satisfaction } \\
\end{array}$ & $\begin{array}{l}\mathrm{r} 1=0,520 \\
\mathrm{r} 2=0,426 \\
\mathrm{~N}=462\end{array}$ & $\begin{array}{l}\text { Transformational } \\
\text { Transactional }\end{array}$ & $\begin{array}{l}\text { MLQ } \\
\text { MSQ }\end{array}$ \\
\hline 13 & Article & 2013 & $\begin{array}{l}\text { Tok, T.N., \& Bacak, E. (2013). Öğretmenlerin iş } \\
\text { doyumu ile yöneticileri için algıladıkları } \\
\text { dönüşümcü liderlik özellikleri arasındaki ilişski. }\end{array}$ & Primary & Aegean & $\begin{array}{l}\text { Independent: } \\
\text { Leadership style } \\
\text { Dependent: } \\
\text { Job satisfaction } \\
\end{array}$ & $\begin{array}{l}\mathrm{r} 1=0,165 \\
\mathrm{~N}=328\end{array}$ & Transformational & MLQ \\
\hline 14 & Article & 2014 & $\begin{array}{l}\text { Tannverdi, H., \& Paşaoğlu, S. (2014). Dönüşüumcü } \\
\text { liderlik, örgütsel adalet ve iş tatmini arasındaki } \\
\text { iliş̧kileri belirlemeye yönelik okul öncesi } \\
\text { öğretmenler üzerinde bir araștırma. }\end{array}$ & Preschool & Marmara & $\begin{array}{l}\text { Independent: } \\
\text { Leadership style } \\
\text { Dependent: } \\
\text { Job satisfaction } \\
\end{array}$ & $\begin{array}{l}\mathrm{r} 1=0,118 \\
\mathrm{~N}=216\end{array}$ & Transformational & MSQ \\
\hline 15 & Article & 2018 & Başaran, M., \& Güçlï, N. (2018). Okul & Primary & Marmara & Independent: & $\mathrm{r} 1=0,558$ & Transformational & MSQ \\
\hline
\end{tabular}




\section{REFERENCES}

References marked with an asterisk indicate studies included in the meta-analysis.

*Akyol Kılıç, M. (2014). Okul öncesi öğretmenlerin yöneticilerinde algıladıkları liderlik stilleri ile kendi iş doyumu düzeyleri arasındaki ilişkinin incelenmesi: İstanbul-Manila örneği. Yayımlanmamış yüksek lisans tezi. İstanbul: Fatih Üniversitesi.

*Aslan, Ü. (2013). Okul müdürlerinin liderlik stilleri ile öğretmenlerin iş doyumu arasındaki ilişkinin incelenmesi. Yayımlanmamış yüksek lisans tezi. Gaziantep: Gaziantep Üniversitesi.

Aydın, A., Sarıer, Y., \& Uysal, Ş. (2013). Okul müdürlerinin liderlik stillerinin, öğretmenlerin örgütsel bağlllı̆̆ına ve iş doyumuna etkisi. Kuram ve Uygulamada Ĕ̆itim Bilimleri, 13(2), 795-811.

Avolio, B. J., Bass, B. M., \& Jung, D. I. (1999). Re-examining the components of transformational and transactional leadership using the multifactor leadership questionnaire. Journal of Occupational and Organizational Psychology, 72(4), 441-462.

Avolio, B.J., \& Bass, B.M. (2002). Developing potential across a full range of leadership: Cases on transactional and transformational leadership. New Jersey: Lawrence Erlbaum Associates.

Bass, B. M., \& Riggio, R. E. (2006). Transformational leadership (2nd ed.). New Jersey: Lawrence Erlbaum Associates.

Bass, B. M. (1985). Leadership and performance beyond expectations. New York: Free Press.

Avolio, B. J., \& Bass, B. M. (1995). Individual consideration viewed at multiple levels of analysis: A multi-level framework for examining the diffusion of transformational leadership. The Leadership Quarterly, 6(2), 199-218. doi:10.1016/1048-9843(95)90035-7

Bass, B. M. (1998). Transformational leadership: Industrial, military, and educational impact. Mahwah, NJ: Lawrence Erlbaum Associates.

Bass, B. M., \& Avolio, B. J. (1997). Full range leadership development: Manual for the multifactor leadership questionnaire. Palo Alto, CA: Mindgarden.

*Başaran, M., \& Güçlü, N. (2018). Okul yöneticilerinin yönetim biçimleri ile öğretmenlerin iş doyumu arasındaki ilişkinin incelenmesi. Gazi Üniversitesi Ĕ̆itim Fakültesi Dergisi, 38(3), 949- 963.

*Benibol, H. (2015). Okul öncesi eğitiminden sorumlu müdürlerinin liderlikstillerinin öğretmenlerin iş doyumu üzerine etkisi. Yayımlanmamış yüksek lisans tezi. İstanbul: Maltepe Üniversitesi.

Bogler, R. (2001). The influence of leadership style on teacher job satisfaction. Educational Administration Quarterly, 37(5), $662-683$.

Bolin, F. (2007). A study of teacher job satisfaction and factors that influence it. Chinese Education ESociety, $40(5), 47-64$

Borenstein, M., Hedges, L.V., Higgins, J.P.T., Rothstein, H.R. (2009). Introduction to meta-analysis. West Sussex, UK: John Wiley \& Sons, Ltd.

Burns, J. M. (1978). Leadership. New York: Harper \& Row.

Bursalığlu, Z. (2010). Okul yönetiminde yeni yapı ve davranış. Ankara: Pegem Akademi.

${ }^{*}$ Canpolat Kirpik, A.N. (2019). Okul yöneticilerinin liderlik tarzlarn ile öğretmenlerin iş doyumu arasındaki ilişkinin incelenmesi. Yayımlanmamış yüksek lisans tezi. Adana: Çukurova Üniversitesi.

Chin, J.M.C. (2007). Meta-analysis of transformational school leadership effects on school outcomes in Taiwan and the USA. Asia Pacific Education Review, 8(2), 166-177.

*Çelebi, C. (2012). İlköğretim okullarında görev yapan okul müdürlerinin okulda gösterdikleri liderlik stilleri ile öğretmenlerin iş doyumu arasındaki ilişki. Yayımlanmamış yüksek lisans tezi. Ankara: Gazi Üniversitesi. 
Çoğaltay, N., Karadağ, E., \& Öztekin, Ö. (2014). Okul müdürlerinin dönüşümcü liderlik davranışlarının öğretmenlerin örgütsel bağlılığına etkisi: Bir meta-analiz çalışması. Kuram ve Uygulamada Ĕ̆itim Yönetimi [Educational Administration: Theory and Practice], 20(4), 483-500. doi: 10.14527/kuey.2014.019

Çoğaltay, N., Yalçın, M., \& Karadağ, E. (2016). Educational leadership and job satisfaction of teachers: a metaanalysis study on the studies published between 2000 and 2016 in Turkey. Eurasian Journal of Educational Research, 62, 255-282, http://dx.doi.org/ 10.14689/ejer.2016.62.13

Çoğaltay, N., \& Karadağ, E. (2016). The effect of educational leadership on organizational variables: a metaanalysis study in the sample of Turkey. Educational Sciences: Theory \& Practice, 16, 603-646.

${ }^{*}$ Çulha, Y. (2017). Okul psikolojik danışmanlarının müdürlerinin liderlik stillerini algılamaları ile kendi iş doyumu ve tükenmişlik düzeyleri arasındaki ilişkinin incelenmesi. Yayımlanmamış yüksek lisans tezi. İstanbul: Maltepe Üniversitesi.

Dinham, S., \& Scott, C. (2000). Moving into the third, outer domain of teacher satisfaction. Journal of Educational Administration, 38(4), 379 - 396.

Dunst, C.J., Bruder, M.B., Hamby, D.W., Howse, R., \& Wilkie, H. (2018). Meta-Analysis of the relationships between different leadership practices and organizational, teaming, leader, and employee outcomes. Journal of International Education and Leadership, 8(2), 1-45.

*Eğriboyun, D. (2015). Ortaöğretim okullarında görev yapan yönetici ve öğretmenlerin liderlik uygulamaları ve iş doyumu algıları arasındaki ilişki. Gaziantep University Journal of Social Sciences, 14(1), 241- 275.

Evans, L. (1997). Addressing problems of conceptualization and construct validity in researching teachers' job satisfaction. Educational Research, 39(3), 319-331.

${ }^{*}$ Genç Yücel, B. (2019). Okul öncesi yöneticilerinin liderlik stilleri ile öğretmenlerin iş doyumu arasındaki ilişki. Yayımlanmamış yüksek lisans tezi. İstanbul: Marmara-İstanbul Sabahattin Zaim Üniversitesi.

Griffin, R. W., \& Bateman, T. S. (1986). Job satisfaction and organizational commitment. In C. L. Cooper \& I. Robertson (Eds.), International review of industrial and organizational psychology (pp. 157 - 188). New York: Wiley.

Hayta, A. B. (2007). Çalışma ortamı koşullarının işletme verimliliği üzerine etkisi. Ticaret ve Turizm Ĕgitim Fakültesi Dergisi, (1), 21-41.

Hulin, C. L., \& Judge, T. A. (2003). Job attitudes. In W. C. Borman, D. R. llgen, \& R. J. Klimoski (Eds.), Handbook of psychology: Industrial and organizational psychology (pp. 255-276). Hoboken, NJ: Wiley.

Judge, T.A., \& Piccolo, R.F. (2004). Transformational and transactional leadership: a meta-analytic test of their relative validity. Journal of Applied Psychology, 89(5), 755-768.

*Kete, D. (2015). Okul müdürlerinin liderlik stilleri ile öğretmenlerin iş doyumu ve örgütsel adalet algıları arasındaki ilişkinin incelenmesi. Yayımlanmamış yüksek lisans tezi. İstanbul: Zirve Üniversitesi.

${ }^{*}$ Kul, M. (2010). Okul yöneticilerinin liderlik stilleri ile beden eğitimi öğretmenlerinin yıldırma (mobbing) yaşama düzeyleri, örgütsel bağlllıkları ve iş doyumu arasındaki ilişki. Yayımlanmamış doktora tezi. Ankara: Gazi Üniversitesi.

Lipsey, M. W., \& Wilson, D. B. (2001). Practical meta-analysis. Thousand Oaks, CA: Sage.

Leithwood, K.A. (1992). The move toward transformational leadership. Educational Leadership, 49(5),8-12.

Leithwood, K., \& Jantzi, D. (1999). The relative effects of principal and teacher sources of leadership on student engagement with school. Educational Administration Quarterly, 35, 679.

Locke, E.A. (1976). The nature and causes of job satisfaction. In M.D.Dunnette (Ed). Handbook of industrial and organizational psychology, (Chicago: Rand McNally, 1976), 1297-1343.

Lowe, K. B., Kroeck, K. G., \& Sivasubramaniam, N. (1996). Effectiveness correlates of transformational and transactional leadership: A meta-analytic review of the MLQ literature. The Leadership Quarterly, 7(3), 385-415. http://dx.doi.org/10.1016/S1048-9843(96)90027-2 
Lytle, N. (2013). Teacher turnover: A look into teacher job satisfaction. Journal of Cross-Disciplinary Perspectives in Education, 6(1), 34-45.

Morris, J. H., \& Sherman, J. D. (1981). Generalizability of an organizational commitment model. Academy of Management Journal, 24(3), 512 - 526.

Newstrom, J.W. (2007). Organizational behavior: human behavior at work. New York: McGraw-Hill Company.

Northouse, P. G. (2010). The leadership: theory and practice (7th ed.). California: Sage Publication.

Ostroff, C. (1992). The relationship between satisfaction, attitudes, and performance: an organizational level analysis. Journal of Applied Psychology, 77, 963-74.

Palupi, D.A.P., Cahjono, M.P., \& Satyawati, E. (2017). Effect of leadership on the job satisfaction with organizational commitment and trust in leader as mediators. Review of Integrative Business and Economics Research, 6 (4), 400-408.

Papanastasiou, C., \& Papanastasiou, E.C. (1998). What influences students to choose the elementary education major: the case of Cyprus. Mediterranean Journal of Educational Studies, 3(1), 35-45.

Papanastasiou, E.C., \& Zembylas, M. (2005). Job satisfaction variance among public and private kindergarten school teachers in Cyprus. International Journal of Educational Research, 43, 147-67.

Qasim, S., Cheema, F.E.A, \& Syed, N.A. (2012). Exploring factors affecting employees' job satisfaction at work. Journal of Management and Social Sciences, 8(1),31-39.

Sarıer, Y. (2013). Ĕ̆itim kurumu müdürlerinin liderliği ile okul çıktıları arasındaki ilişkilerin meta-analiz yöntemiyle incelenmesi. Yayımlanmamış doktora tezi. Eskişehir: Osmangazi Üniversitesi.

Schyns, B., \& Schillng, J. (2013). How bad are the effects of bad leaders? A meta-analysis of destructive leadership and its outcomes. The Leadership Quarterly, 24, 138-158.

Statt, D. (2004). The Routledge dictionary of business management (3 ${ }^{\text {rd }}$ ed.). Detroit: Routledge Publishing.

Steers, R. M., \& Rhodes, S. R. (1978). Major influences on employee attendance: a process model. Journal of Applied Psychology, 63(4), $391-407$.

Sypniewska, B.A. (2013). Evaluation of factors influencing job satisfaction. Contemporary Economics, 8(1), 57-72.

${ }^{*}$ Tanrıverdi, H., \& Paşaoğlu, S. (2014). Dönüşümcü liderlik, örgütsel adalet ve iş tatmini arasındaki ilişkileri belirlemeye yönelik okul öncesi öğretmenler üzerinde bir araştırma. Electronic Journal of Social Sciences, 13(50), 274-293.

Thompson, D.P., McNamara, J.F., \& Hoyle, J.R. (1997). Job satisfaction in educational organizations: a synthesis of research findings. Educational Administration Quarterly, 33, 7-37.

*Tok, T.N., \& Bacak, E. (2013). Öğretmenlerin iş doyumu ile yöneticileri için algıladıkları dönüşümcü liderlik özellikleri arasındaki ilişki. International Journal of Human Sciences, 10(1), 1135-1166.

Toropova, A., Myrberg, E., \& Johansson, S. (2020): Teacher job satisfaction: the importance of school working conditions and teacher characteristics. Educational Review, DOI: 10.1080/00131911.2019.1705247

*Tura, M. (2012). Illköğretim okulu müdürlerinin liderlik stillerinin öğretmenlerin iş doyumuna etkisi: Karacabey ilçesi örneği. Yayımlanmamış yüksek lisans tezi. Balıkesir: Balıkesir Üniversitesi.

Üstün, U., \& Eryılmaz, A. (2014). Etkili araştırma sentezleri yapabilmek için bir araştırma yöntemi: Metaanaliz. Ĕ̆itim ve Bilim, (39), 174, 1-32.

Weiss, D. J., Dawis, R. V., England, G. W. \& Lofquist, L. H. (1967). Manual for the Minnesota Satisfaction Questionnaire. University of Minnesota: Minnesota Studies in Vocational Rehabilitation.

*Yılmaz, T. (2014). Özel okullardaki ilkokul müdürlerinin liderlik biçimi ile sınıf öğretmenlerinin iş doyumu arasındaki ilişki. Yayımlanmamış yüksek lisans tezi. İstanbul: Okan Üniversitesi. 